\title{
Democratic Governance: Civil Society Participation in Migrant Worker Advocacy
}

\author{
Achmad Nur \\ Public Administration Department, Faculty of Social Sciences, Universitas Negeri Yogyakarta \\ (email: achmadnur40@gmail.com) \\ Dwi Harsono \\ Public Administration Department, Faculty of Social Sciences, Universitas Negeri Yogyakarta \\ (email: dwiharsono@uny.ac.id)
}

\begin{abstract}
This article was (1) to examine the process of democratic governance carried out by Yogyakarta Legal Aid Institute through advocating the Erwiana case and (2) to find out the supporting and inhibiting factors in promoting democratic governance. This study is descriptive qualitative research. The informants were the director, head of the division, and members of Yogyakarta Legal Aid Institute and Erwiana as the beneficiary. Data collection techniques used non-participant observation, interviews, and documentation studies and followed with data sources triangulation to check its validity. The data analysis then applied an interactive model through data collection, data presentation, verification, and conclusions. The results showed that the Yogyakarta Legal Aid Institute's implementation of democratic governance in advocating law enforcement on the injustices experienced toward migrant workers was optimal. As an NGO, LBH has been able to bridge differences in legal policies between the two countries and efficient against diplomatic barriers. Its supporting factors are political development as mobilization and mass participation, collaboration with grassroots groups, donor support, and public policies that support case counseling. Simultaneously, the inhibiting factors are political will, intolerant group resistance, and lack of human resources.
\end{abstract}

\section{Keywords:}

democratic governance; advocacy; legal aid; NGO; migrant worker

\section{Introduction}

Population growth is inevitable for any country. Indonesia is one of them. Population growth will impact economic growth with three possibilities: inhibiting, supporting, or even having no impact (Remi et al., 2017: 2). Thus, population growth needs to address the gap between winners and those defeated in competition in the labor market (The World Bank, 2002: 87). Nevertheless, jobs' availability does not meet the population growth (Tjiptoherijanto, 2001: 6). Ideally, between the two, there is a dialogue in planning community 
development. Thus, between the two occur synergy that results in simultaneous relationships and mutual influence (Ranis \& Stewart, 2005: 13; Remi et al., 2017: 21).

The availability of jobs encourages competition among job seekers. The availability of jobs, especially in rural areas (Novianti, 2010: 15), makes the brain-turning community look for alternatives to be still able to meet basic needs. Working abroad is the best option for some people, rather than living miserably even though the government issued a zero-maid policy in 2015. Agustini (2012: 1) noted two economic factors that drive a person to become an Indonesian Labor (TKI), namely the ability to meet basic needs and family dependents.

TKI is not without risks. Some of the risks that migrant workers can experience include unpaid wages, physical violence, sexual harassment, and overload (Novianti, 2010: 16). Unfortunately, not all migrant worker understands how to solve problems that are at the same time an externality of fragile labor protection. On the other hand, Law No. 18 of 2017 on the Protection of Indonesian Migrant Workers article 2 point (d) prioritizes the principle of democracy in implementing labor protections. Democratic actors need to take a role in their implementation of labor protection.

Indonesia has experience dealing with labor problems abroad. The female Workforce (TKW) dominates Indonesian citizens who face the law in the country of placement (hosted country). The proportion of TKW is inversely proportional to the number of TKI (male), which reached $60.48 \%$ in 2015 (Hutagalung \& Indiro, 2019: vii). It tends that female workers are more susceptible to discrimination. One of them was Erwiana, who received discriminatory action from her employer, Law Wan-Tung, in Hong Kong. Erwiana doesn't know how to get justice. Erwiana appointed Yogyakarta Legal Aid Institute (LBH Yogyakarta) as a legal authority.

By the practice of democracy, the state upholds human rights and opens the wide door of people's participation. LBH Yogyakarta, together with non-governmental organizations (NGOs), fill the vacancy of the role or instead collaborate with the government. The role of NGOs is the expression of freedom of association and the spirit of enforcing human rights. For LBH Yogyakarta, the oppression of human rights is unjustified. If it is not in question, it means democracy in Indonesia is not okay. Thus, looking at NGOs' performance no longer rests on the programs and the public value.

March \& Olsen (1995: 12) defines democratic governance as ".. seen as converting individual wants and resources into collective action by discovering and implementing policy 
coalitions that arrange Pareto-improving exchanges among citizens". From an institutional perspective, democratic governance not only governance management of coalition development and exchange of interests in a limited time (March \& Olsen, 1995: 44). Democratic governance values occur if the management process is carried out. The conflicts that arise during the country's political dynamics can develop common understandings (citizens), arguments, and reasons.

Democratic governance requires community participation. Stelcher and Torfing (1999) in Rahayu \& Juwono (2019: 80) classify the form or way of government in collecting people's aspirations as follows: (1) Data gathering through public surveys; (2) Opinion seeking through public consultation; (3) Policy exploration through deliberative forums; and (4) Interactive dialogue through governance networks. Internalization of democratic governance, according to Weiss in Suharko (2005: 268), about the case of Erwiana can be done by looking at the following:

1. Universal protection of human rights.

2. Non-discriminatory laws.

3. Efficient.

4. Impartial and rapid judicial processes.

5. Transparent public agencies.

6. Accountability for decisions by public officials.

7. Meaningful participation by a citizen in debating public policies and choices.

NGOs' existence is often only seen from how much it contributes to the work program measuring instruments. More than that, every NGO "activist" has a targeted value that is the institution's purpose. LBH Yogyakarta is one of the supporters of upholding democratic values and its optimistic existence towards democratic governance. Therefore, researchers are interested in seeing how LBH Yogyakarta promotes democratic governance in Erwiana's advocation started in 2014 as a case of NGO activities accompanying TKI on litigation and non-litigating processes.

\section{Methods}

This type of research is descriptive research with a qualitative approach. The research was conducted in February - July 2020, located at the Legal Aid Institute (LBH) Yogyakarta. 
The subjects in this study include (1) Yogi Zul Fadhli as Director of LBH Yogyakarta, (2) Budi Hermawan as Head of Advocacy Division, (3) Meila Nurul Fajriah as PID Division Staff, (4) Juanda Albert as PID Division Staff, (5) Abdul Malik Akdom as Staff of Advocacy Division, (6) Wahidul Halim as APBH, and (7) Erwiana Sulistyaningih as access to legal aid services. This study collected data through observations, interviews, and documentation. This study's analysis techniques use data analysis techniques developed by Bungin (2003: 70), including data collection, data reduction, data presentation and verification, and drawing and conclusions.

\section{Results and Discussion}

Erwiana received discrimination from her employer in Hong Kong. She was not paid, did not get any day off, was not provided with enough food until it was physically persecuted. The condition harmed Erwiana as a migrant worker. In fact, in the end, Erwiana's employer intended to return her to Indonesia and only provided with a plane ticket and pocket money equivalent to $\operatorname{Rp} 100,000.00$. A fellow Indonesian worker who was also going back to Indonesia met Erwiana at the airport and initiated to inform the irony of the TKI from Sragen Regency through social media. The public took seriously the inhumane actions taken by Erwiana's employer. This problem continues because of the law. In the end, Law Wan Tung, Erwiana's employer, was found guilty by a Hong Kong court and sentenced to seven years in prison on February 10, 2015.

Erwiana appointed LBH Yogyakarta as a legal authority during the handling of the case. LBH Yogyakarta is not alone. LBH Yogyakarta cooperates with law organizations in Hong Kong and the Indonesian Migrant Workers Network in Hong Kong. The Indonesian Labor Association (ATKI) and the Indonesia Migrant Worker Union (IMWU) pressure the Hong Kong Police to process the perpetrators of persecution of migrant workers immediately.

LBH Yogyakarta does more legal aid work required from Indonesia. In Hong Kong, Erwiana Sulistyaningsih has a legal authority that also handles her case. LBH Yogyakarta marginalized Erwiana Sulistyaningsih by preparing evidence for trial in a court in Hong Kong. LBH Yogyakarta accompanied the process of making news of the Inspection Event (BAP), which also involved the Hong Kong Ministry of Manpower. On the other hand, LBH Yogyakarta serves as a liaison between Erwiana Sulistyaningsih and her lawyer in Hong 
Kong. This procedure was a significant move because the court in Hong Kong did not provide a translator. Besides, it is a strategy in response to the legal system's differences in both countries.

Although LBH Yogyakarta handles cross-border cases, the institution does not leave the characteristics of legal aid assistant under the auspices of YLBHI, namely by carrying the spirit of structural legal aid. On the other hand, LBH Yogyakarta provides additional services in trauma healing for Erwiana Sulistyaningsih. LBH Yogyakarta not only aspires to win cases in court but also conducts political campaigns. Political campaigns are carried out as educational measures and a means of introducing institutions to the public. With more and more widely known, LBH Yogyakarta will more easily internalize democratic values.

\section{Implementation of Democratic Governance conducted by LBH Yogyakarta}

Democratic governance values appear in advocacy cases; for example, in the Erwiana case, although not necessarily the institution calls it on its vision and mission, nevertheless, implicitly, LBH Yogyakarta is practicing democratic governance. Table 1 summarized the implementation of democratic governance by LBH Yogyakarta. It discussed the indicators in more detail.

1. Universal protection of human rights

The case of Erwiana Sulistyaningsih, as one of many cases, has been accompanied by LBH Yogyakarta. Case advocacy is LBH Yogyakarta's strategy in democratizing. Case advocacy is like an entrance to make the public aware that existing policies still have loopholes. This practice is the function of NGOs, which is to oversee the performance of legislation. LBH Yogyakarta sees there is a structure that harms the community.

Society faces a vulnerable structure. Economically depressed people have to turn their brains around to meet basic needs. Erwiana Sulistyaningsih is an example of how working abroad is so tempting despite the risks. The fulfillment of fundamental rights is the state's obligation, including the right to obtain a job in its own country. For Erwiana Sulistyaningsih, education is a gap in getting a profitable job position in the past before working abroad. Education is an essential service.

Erwiana Sulistyaningsih's case advocacy played a role in encouraging democratization. Democracy provides recognition for the public to participate widely in governance. LBH 
Yogyakarta is a public entity consisting of communities that are empowered to fill the space. LBH Yogyakarta provides available services to the public in legal consulting services to provide free legal assistance. Armed with Structural Legal Assistance, LBH Yogyakarta diligently includes unfavorable policy recommendations to the community.

Through the advocacy of Erwiana's case, LBH Yogyakarta encourages the country to commit to fulfilling the people's fundamental rights, including migrant workers abroad. Respect for human rights is a crucial step to strengthen democracy in a country. Thus, the creation of social resilience is not only hoping in the future.

2. Non-discriminatory law

LBH Yogyakarta responds to the situation on the ground. The linguistics of the people who are fighting for their rights are the target of work. The success in the handling of cases so far makes LBH Yogyakarta credibility to fight for human rights. LBH Yogyakarta also learns a lot from the community. Institutions understand how people eagerly fight for their rights even though they do not initially know how the law works in Indonesia.

Cross-issue consolidation is an absolute strategy. However, LBH Yogyakarta is more selective in selecting "friends" based on the issue. But there are different stories when agencies are trying to gather knowledge for capacity building - the purpose is to maintain the agency's commitment to improving existing structures. For example, in Erwiana Sulistyaningsih, it will eventually boil down to employment policy, especially migrant workers. But in fact, many systems that govern the economy are the focus. Thus, LBH Yogyakarta needs consolidation to enrich knowledge.

Requests for legal consulting services are always coming. It has two possibilities. First, there is public trust in LBH Yogyakarta in dealing with human rights cases. Or, secondly, more and more human rights violations, like mushrooms in the rainy season. LBH Yogyakarta responds to every community that comes to consult. The institution's priority in accompanying cases to the court's realm is structural cases well noted.

Indonesia has ratified the Convention on Civil and Political Rights and the Convention on Economic, Social, and Cultural Rights. The consequence of such ratification is that Indonesia must recognize every fundamental right of society mandated by the covenant. Existing public policy should reflect the rationing of human rights values. LBH Yogyakarta provides legal assistance to the community as a form of respect for human rights itself. 
Because when there is a policy that harms human rights, then there can undoubtedly be discrimination. Accordingly, it exercises the agency's commitment to improving the structure.

Democratic governance has a positive impact on realizing equality for the TKI. Erwiana Sulistyaningsih, who gets inhumane action, can still demand her rights as a worker. The constraints encountered in learning equality, especially for the poor and marginalized, are shared with the net. Thus, the application of democratic governance by LBH Yogyakarta can affect the fate of poor people facing legal problems.

\section{Efficient}

LBH Yogyakarta conducts efficiencies in conducting case advocacy work. Efficiency is measuring how good case handling is. The selection of strategies begins with all efforts, including research directly in the middle of society. LBH Yogyakarta does not hesitate to go to the community to ensure the latest conditions in the field. Of course, if understood with glasses Structural Legal Aid, this is a decisive action to put together synergistic efforts with the community.

The service procedures in LBH Yogyakarta carried out the assistance of Erwiana Sulistyaningsih's case. The Advocacy Division conducted case assistance in LBH Yogyakarta. LBH Yogyakarta conducts litigation assistance as well as non-litigation. In the case of Erwiana Sulistyaningsih, she appointed LBH Yogyakarta as her legal authority. But daily, case assistance can go from legal evolving to court case settlement.

LBH Yogyakarta checks the reported cases. It starts with dig up information related to the case's sitting and the case's origin. Re-check by meeting with key people and digging up information. The person is the one who has a relationship with the accompanying case. After being found to be sitting the case, LBH Yogyakarta then held a Focus Internal Group Discussion (FIGD). FIGD activities involved key people connected with the issue. The purpose of FIGD is to equate the view between key people in looking at the case faced. This FIGD will support the focus group discussion (FGD) in a large forum community that gets injustice from the case. FGD submitted the FIGD results and explained to the public to determine what action to take. The steps taken next may be action, litigation, and non-litigation. Of course, this step is the result of a joint agreement with the community seeking justice.

The following step is to act. In this case, the underlining action is not always in the form of anarchic democrat but rather an action to negotiate with the people's interests. After the 
action, it arrives to evaluate whether it is fit for purpose or not. If the effort fails, then the result will be brought back to FIGD to discuss whether that caused the action to fail and set its strategy until re-evaluation, so on.

Legal assistance services were provided by LBH Yogyakarta to Erwiana well. Although there are often obstacles during the case's assistance, the LBH Yogyakarta can resolve the barrier due to its organization's culture. Thus, it assures the sustainability of legal aid services.

Table 1.

The Implementation of Democratic Governance in LBH Yogyakarta

\begin{tabular}{l} 
No Description \\
\hline 1. Universal protection of human rights \\
a. LBH Yogyakarta responds to human rights policy, e.g., protection of TKI \\
b. LBH Yogyakarta uses the point of view of Structural Legal Aid \\
c. LBH Yogyakarta conducts policy advocacy as part of efforts to create a better structure \\
d. LBH Yogyakarta provides legal consulting services for the community \\
e. LBH Yogyakarta provides free legal aid \\
f. LBH Yogyakarta conducts legal education to the people \\
g. Actions include nets (based on issue), campaigns, research, organizing to litigation \\
h. LBH Yogyakarta as a catalyst
\end{tabular}

2. Non-discriminatory laws
a. Responding to a human rights policy
b. LBH Yogyakarta conducts a review of policies that support human rights enforcement
c. LBH Yogyakarta conducts policy advocacy if there is a possibility of discrimination for the community
d. After completing a review of public policy, LBH Yogyakarta provides policy recommendations
e. LBH Yogyakarta responds to the situation in the field (linguistics of the people who are fighting for their rights)
f. Consolidate across issues

3. Efficient
a. LBH Yogyakarta conducts efficiently in conducting case advocacy work
b. LBH Yogyakarta builds a network of work to maximize case advocacy results
c. LBH Yogyakarta runs structural, legal aid education through Kalabahu Program and Paralegal School
d. LBH Yogyakarta held an internal meeting as the first step in resolving the case
e. Regional Working Meeting (Rakerda) as the beginning of the annual movement

4. Impartial and rapid judicial

a. LBH Yogyakarta gives access to legal aid to the community

b. LBH Yogyakarta positions society as having the highest sovereignty 


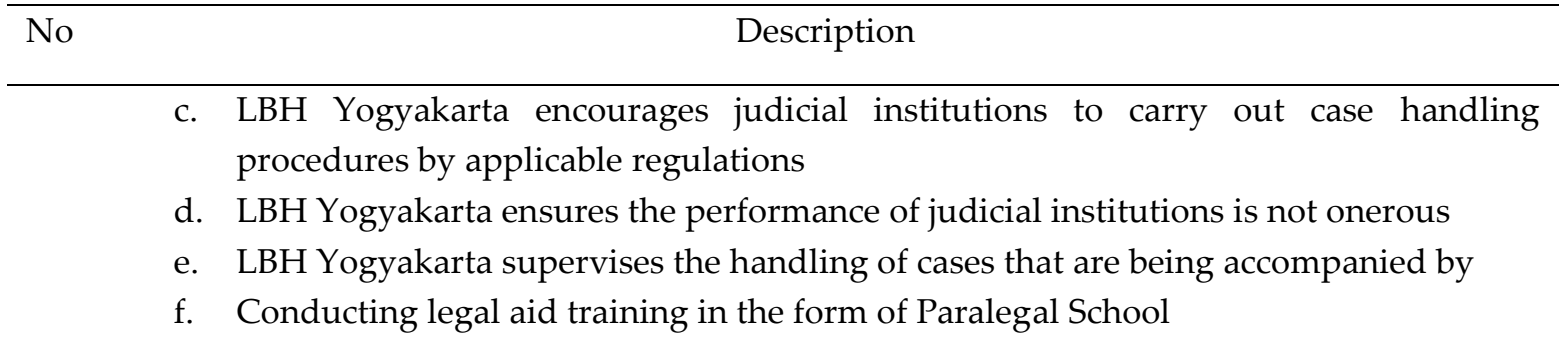

5. Transparent public agencies
a. LBH Yogyakarta supports transparency through regulations that support advocacy work, for example, to obtain information for the optimization of case assistance results
b. If it encounters difficulties, then what to do is sending a letter, to have a public dialogue or protest
c. Disclosure of information provided by LBH Yogyakarta is in the agency's report, in the form of Year-End Notes (Catahu)
d. Using social media as a means of disseminating information
e. Conduct financial audits
f. Conduct performance audits but has no obligation to report them to the Government

6. Accountability for decisions by public officials
a. LBH Yogyakarta engages the community in organizational activities, for example, in Regional regulation
b. LBH Yogyakarta encourages public institutions to hold the public accountable
c. LBH Yogyakarta conducts accountability by issuing Catahu every year
d. Accountability both vertically and horizontally

7. Meaningful participation by a citizen in debating public policies and choices
a. LBH Yogyakarta encourages people to participate in the development of actively
b. LBH Yogyakarta encourages people to know their rights
c. The community position is a critical prerequisite in legal case advocacy work.
d. LBH Yogyakarta conducts critical legal education for people who experience discriminatory actions
e. Paralegal schools in a bid to establish grassroots legal aid force.
f. Efforts to grow social capital

Source: obtained from primary data

\section{Impartial and rapid judicial processes}

LBH Yogyakarta conducts monitoring of judicial institutions that functionates NGOs in terms of democracy. Monitoring is carried out in one direction, by LBH Yogyakarta to the judicial institutions. LBH Yogyakarta encourages judicial institutions in Indonesia to respect the ILO 189 convention content agreed upon within other countries. Based on the agreement, the Government of Indonesia should consistently guarantee workers' basic rights, including 
domestic workers' fundamental rights, information on the terms and conditions of employment, working hours, employment, and safety, occupational health, and social security.

In the handling of Erwiana Sulistyaningsih's case, LBH Yogyakarta used the situation as momentum to campaign for workers' rights, especially in the informal sector. LBH Yogyakarta prioritizes the principle of professionalism during the mentoring of cases and often interact with public agencies. Still, there is no relationship with a thing but the interaction between NGOs and the state. Such monitoring is usually carried out by LBH Yogyakarta to ensure that any complaints or cases handled are responded to by the procedures applicable in the relevant agencies. Thus, LBH Yogyakarta is reducing the likelihood of maladministration occurring.

The Advocacy Division became a pivot in advocacy activities and involved all elements of the organization. The assignment to the Advocacy Division facilitated the follow-up step of each incoming case. This does not overlap the case because the Advocacy Division has handled the case entered through legal consultation. It would be easier if the person in charge of the case assistance became part of the division and AD and ART mandate.

LBH Yogyakarta provides access to legal aid to the community. The public service is protected by Law No. 16 of 2011 On Legal Aid. People dealing with legal problems do not always understand how to act and even know the service flow. LBH Yogyakarta fills the role of the state, namely, as a legal aid provider. Indeed in legal consulting services, all kinds of problems will be served by the institution, particularly the structural cases. The consequences of structural matters may harm incapable people. Losses are measured not only economically but also socially, politically, culturally, and legally.

LBH Yogyakarta contributes to ensuring better use of resources in the judicial process for a balanced verdict and siding with the truth. In the case of Erwiana, LBH Yogyakarta monitors the judicial process to run as it should increase participation and motivation in the case's assistance.

5. Transparent public agencies

LBH Yogyakarta supports transparency through regulations that support advocacy work. For example, to get information for optimizing the LBH Yogyakarta case's assistance, it will contact public agencies. What to build is a formal communication between agencies? LBH 
Yogyakarta also cooperates with other public institutions, such as the Ombudsman and the National Commission for the Protection of Human Rights (Komnas HAM). If it encounters difficulties, then what is done in public dialogue or even protest, as the last effort. Transparency indicates that direct information from public agencies is vital in handling cases supported by Law No. 14 of 2008 on Public Information Disclosure. The public policy opens up space for NGOs to access general information as a form of freedom in a democratic country.

The disclosure of LBH Yogyakarta information is open to the public in the agency's report, Year-end notes (Catahu). Catahu contains various information, including agency profiles, infographics, case summaries, and conclusions on conditions during a year in the work area, including a financial report in Catahu Year 2019. The public can access Catahu on the agency's official website http://www.lbhyogyakarta.org. The public can assess activity updates through various social media, including Facebook, Twitter, and Instagram. The use of social media is further to expand the influence of institutions through regular news. It is also to raise public trust in LBH Yogyakarta.

LBH Yogyakarta conducts audits. The audit seeks to find out the organization's internals. On the other hand, an audit can also determine whether the legal aid movement is effective and efficient or not, seen from various organization's operational activities. LBH Yogyakarta conducts two kinds of audits, namely financial audits and performance audits. First, financial audits purpose is to determine the financial condition of institutions to support organizational movements. An appointed public accountant conducted the audit by LBH Yogyakarta. Second, performance audits. Performance audits find out the delve into the state of the organization. However, as an NGO, LBH Yogyakarta has no obligation to report the public's audit results, including the government.

LBH Yogyakarta encourages easy access to public information. In line with this, the agency promotes the optimization of resources to improve public sector management's efficiency and effectiveness, especially legal services and legal aid.

6. Accountability for decisions by public officials

LBH Yogyakarta does accountability by publishing Catahu every year. Although it has no obligation to hold the public accountable, LBH Yogyakarta does as well. Catahu signaled that LBH Yogyakarta is spreading influence on readers. The democratic values raised are 
illustrated by why a public problem can occur, how the suffering of oppressed people, how cases handled, and how ideal democracy is. Call it the Erwiana Sulistyaningsih case. The economic structure that prompted Erwiana Sulistyaningsih to complain abroad was also the leading cause of most TKI. Erwiana Sulistyaningsih faced with two choices: surviving with economic inequality or becoming a TKI for a better life. However, Erwiana Sulistyaningsih seeks justice. The employer's abusive treatment of her is a form of torture every day. LBH Yogyakarta accompanied the case in cooperation with elements of civil society. As a result, Erwiana Sulistyaningsih is winning the case. Long story short, from the long journey Erwiana Sulistyaningsih demanded justice. It took the common thread that LBH Yogyakarta can give an example if the country is absent. Then, it will also encourage inhumane actions for its citizens working abroad.

Accountability, both vertically and horizontally, occurs in LBH Yogyakarta. Vertical accountability describes interactions between positions within the organization. Members of the division must report the work results to the head of the division. The head of the division is obliged to convey the development of the work program to the director. On the other hand, the interaction of LBH Yogyakarta with the external environment can also be a form of vertical accountability, for example, between LBH Yogyakarta and Tifa Foundation to strengthen community capacity through Paralegal School. Horizontal accountability applies to equivalent levels, e.g., coordination between fellow division members or division heads. However, LBH Yogyakarta does not necessarily convey internal conditions to interested parties because there are conditions where internal organizations only become members' consumption, such as more detailed funding.

LBH Yogyakarta strives not to make the organizational structure an inhibition of advocacy work. Administrative and rigid procedures turned into as minimal as possible. The expected result is a dynamic and harmonious interaction between members. Administrative activities may create bulkheads amid efforts to make cases. Of course, it does not benefit the organization because every action must be precise, not flexible. It is also spelled out on the organizational structure's delivery through the website by not including the organization chart, even though there is an indication of name and position. Like two sides of a coin, the option has a role in triggering coordination constraints that allow for contradictions. 
LBH Yogyakarta promotes the poor's interests, such as access to legal aid services for migrant workers, such as Erwiana. Also, institutions contribute to preventing abuse of power and maladministration. In the end, accountability mechanisms can increase stakeholders' resistance to LBH Yogyakarta, such as avoiding discrimination measures to the TKI.

7. Meaningful participation by a citizen in debating public policies and choices

LBH Yogyakarta encourages people to know their rights. The fulfillment of rights for the community affected by development programs, for example, is easier to do when it has the least awareness that it is facing injustice. Thus, people have responded to policies that are a choice of actions taken by the authorities. The community position is a critical prerequisite in legal case advocacy work. Structural legal aid does not want a stuttering society of the law. As long as the community lives in the law's territory, there is no reason not to understand the prevailing law. Advocacy is an effort to re-fulfill the harmed's rights so that the public should realize from the very early days what is right.

LBH Yogyakarta conducts critical legal education for people who experience discriminatory actions. LBH's participation is in a variety of ways. LBH Yogyakarta participates in advancing the community's welfare by complementing the state's role as a public servant. Education is defined as a form of encouraging people to have power. Thus, it is not appropriate that the educational process only exists when sitting in the classroom while listening to a teacher's talk. Meanwhile, LBH Yogyakarta conducts critical legal education in assisted society with various methods, such as discussion, because the people in litigation will be more interested in practical measures to solve the problem in front of the eyes.

Legal education conducted directly to the community encourages the formation of social capital. The most commonly internalized material is related to human rights. This is important because the foothold why LBH Yogyakarta conducts mentoring is an oppressive structure. In other words, by seeking the realization of social capital, the network will start to change for the better-for example, the trust aspect. People will be more confident that they also can oppose oppression, not just as the aggrieved party of development programs: another example, networking. Communities tied to the same interests are rallying forces to ensure human rights. Thus, the increased capacity is no longer a public figure but will be more evenly distributed, even forming a new community. However, it is not uncommon to find a passive society. The incomprehension of the legal mechanisms that apply is the beginning of people's 
desperation to choose passively or participate but with a minimal portion. This indicates that there are still people who are confused when faced with legal problems. This will also make it easier for LBH Yogyakarta to conduct social studies to strengthen assisted communities' bargaining values.

Paralegal schools establish legal aid forces at the grassroots. The participation of LBH Yogyakarta as an NGO increases the community's capacity to internalize democratic values actively. On the other hand, society is encouraged to be active, especially about the law. Paralegal Schools is an overview of how an NGO conducts a movement that targets grassroots communities but involves other communities. Call it a think tank. The organization appoints one or more representatives to attend the Paralegal School. Each representative is given legal aid material and honed skills in understanding social reality with an approach to issues close to the community. In the middle of the session, $\mathrm{LBH}$ is evaluating each community leader in Yogyakarta. The assessment purposes at conveying the development of the educational achievements of each community representative. $\mathrm{LBH}$ is considering at the end of the learning period. From this, LBH Yogyakarta realizes the mechanism of representation for each community. The community deliberations are conducting to determine who to choose. At the end of education, the evaluation became a form of accountability delivery of LBH Yogyakarta as a program maker to the community as the party that receives the program's benefits.

The formation of a community from a co-assisted community is another form of participation. People dare to express their aspirations. Furthermore, the articulation of interests is essential in joint with LBH Yogyakarta. However, the birth of legal aid cadres from the assisted communities through critical legal education is a new spirit for LBH Yogyakarta. A change agent in a conflicting society is necessary to help control conflict management development. Conflict resolution is more accessible from within, which is what LBH Yogyakarta believes. The community supports legal aid work as appropriate. Starting from the willingness to participate in the fight for human rights, it paved the way for realizing organic solidarity due to critical legal education. This solidarity is essential, considering that people are always face-to-face with opponents of the cause, including NGOs opposed to ideology with LBH Yogyakarta.

LBH Yogyakarta, as an NGO, feels a responsibility, initiates, and is committed to encouraging participation on an ongoing basis. In Erwiana, LBH Yogyakarta, together with 
the network, mobilized to pressure the authorities to respond to the matter as a serious problem. The ultimate goal of the participation process is a change to public policy that is more pro-community.

\section{Supporting and Inhibitory Factors of Non-Governmental Organizations Promoting Democratic Governance}

In implementing democratic governance, some factors affect the organization's performance, not least with LBH Yogyakarta. LBH Yogyakarta reflects how democratic governance in promoting its capacity as NGO.

\section{Supporting Factors}

a. Political development as mobilization and mass participation

A democratic system can mobilize people's resources more efficiently. In contrast to the statement, there is a presumption that efforts to introduce democracy can be an obstacle to development rather than appropriate if juxtaposed with social work carried out by LBH Yogyakarta. The living space of transformative NGOs, such as LBH Yogyakarta, is an arena to find alternatives to the renewal of conditions supported by countries that are not always capable. The state's inability to provide free legal assistance services that are popular is an opportunity for the entrance of LBH Yogyakarta to take on the role. On the other hand, NGOs can also mobilize people to fight for fundamental rights actively. At the same time, the NGO itself can maintain its existence based on issues of priority.

b. Cooperation with grass-root groups

The strength of the people's organization is a crucial supporting factor. Many NGOs are unable to maintain their effectiveness due to the lack of established network work. Each NGO tends to put its ideology first. However, in some cases, an organization's selfish side will be minimized to achieve the organization's goals. LBH Yogyakarta was indexed while handling the case of Erwiana Sulistyaningsih. LBH Yogyakarta cooperates with other NGOs. Nevertheless, LBH Yogyakarta still chooses colleagues who are in line with the addressed issues.

c. Donor Support

It has become a common understanding that most NGOs have independent funding, including LBH Yogyakarta. LBH Yogyakarta has a diverse source of funds. The agency's 
budget comes from donor grants and merchandise sales through the official Instagram @sobatkeadilan. The Tifa Foundation grant for the Paralegal Schools program supports legal aid education for community representatives. The two institutions are equally encouraging respect for human rights. Thus, it is appropriate if LBH Yogyakarta gets support from Tifa Foundation. Donor support for NGOs is not just financial. From LBH Yogyakarta, for example, the implementation of Paralegal School gives an idea that there are efforts to encourage people to be active as well as a civil society capacity building plan to meet a more democratic state life.

d. Public policy that supports litigation assistance

LBH Yogyakarta public service is legal aid for the poor who have difficulty in accessing it. In this way, of course, the movement of the institution needs to get legality. Concerning legal aid, there is a Legal Aid Act. The Legal Aid Act may be new to ensure access to lawyers. However, the Paralegal Act changed to justice for people who are not legal scholars only limited to non-litigation.

2. Inhibitory Factors

a. Political will

Arbitrary policies open up opportunities for injustice for society. Public policy is an intrusion that forces every state's element to act according to the content, thereby. In contrast, the existence of a public policy is inseparable from the possibility of overlap. This kind of thing is troublesome for NGOs to do defense for the community to demand justice. Decentralization has another face that widens the Local Government's case inviting policies that are different from those that already exist at the national level, regardless of the context of good or bad for the community. Arbitrary systems will never benefit society, both given its implementation and its impact on the structure. Not to mention, NGOs faced with convoluted bureaucracy.

b. Intolerant group resistance

There is a rejection from NGOs that differ from the principles embraced by LBH Yogyakarta. Intolerant groups are pinned to civil society elements that are not yet or even unprepared for the difference in their fellow viewpoints. LBH Yogyakarta fights for the fundamental rights of society. Religious groups are often cross-understanding with LBH Yogyakarta. 


\section{c. Lack of Organisational Human Resources}

Human Resources Organization is the determinant of the success of LBH Yogyakarta internalizing democratic values. However, the number is not yet comparable to the case number. LBH Yogyakarta has a Legal Aid Training Work (KALABAHU) as a means of supporting cadreization. However, it has not been adequate for the cadreization of institutions when applying to become a Legal Aid Minister $(\mathrm{LBH})$ is not comparable to the total number of Kalabahu participants. Based on Catahu 2019, LBH Yogyakarta received 200 complaints.

Meanwhile, LBH Yogyakarta only has $27 \mathrm{PBH}$. The area of work covers the entire DI Yogyakarta and 15 districts and cities in southern Central Java. Fortunately, LBH Yogyakarta has paralegals working on their respective community bases even though there is no attachment to the institution's relationship.

\section{Conclusion}

Based on the above description, the study concluded that implementing democratic governance on the work of court assistance as a case advocacy effort by the Legal Aid Institute (LBH) Yogyakarta is optimal. Erwiana managed to get justice as a migrant worker (TKI) who received her employer's discriminatory actions in Hong Kong. Nevertheless, LBH Yogyakarta experienced new obstacles to political will resistance from intolerant groups and a lack of organizational human resources. In the case of Erwiana Sulistyaningsih, LBH Yogyakarta gives the idea that NGOs can also play a role in providing services to the community like those offered by the state when the state is sluggish, absent, or even as a perpetrator of discrimination. Democratic governance values internalized during the management process, and conflicts that occur during the country's political dynamics can develop a shared understanding of the meaning of national and state life. Therefore, citizens need to play an active role in controlling public policy that affects themselves as individuals and communities, even if few. It is also a consequence that democracy can still exist if people take part while NGOs are more than catalysts. Thus, LBH Yogyakarta needs to improve the cadreization strategy to attract the public to join and fight for the fate of others who are experiencing unfair actions. 


\section{References}

\section{Books}

Agustini, R. (2012). Karakteristik Tenaga Kerja Wanita (TKW) yang Pernah Bekerja Ke Luar Negeri dan Dampak Remitensi Terhadap Keluarga Tenaga Kerja Wanita Di Kecamatan Sepulu Kabupaten Bangkalan. Malang: Jurusan Geografi Fakultas Ilmu Sosial Universitas Negeri Malang.

Bungin, B. (2003). Analisa Data Penelitian Kualitatif: Pemahaman Filosofis dan Metodologis ke Arah Penguasaan Model Aplikasi. Jakarta: Raja Grafindo Persada.

Hutagalung, S. A., \& Indiro, V. T. (2019). Laporan Tematik Studi Midline MAMPU Tema 3: Akses Perempuan Buruh Migran Luar Negeri terhadap Layanan Perlindungan. Jakarta: The SMERU Research Institute.

Moleong, L. J. (2014). Metodologi Penelitian Kualitatif Edisi Revisi. Bandung: PT REMAJA ROSDAKARYA.

Rahayu, A. Y., \& Juwono, V. (2019). Birokrasi \& Governance Teori, Konsep, dan Aplikasinya. Depok: RAJAWALI PERS.

Remi, S. S., Hadiyanto, F., Muljariyadi, B., Purnagunawan, M., Fahmi, M., Siregar, A. Y., . . . Kharisma, B. (2017). Strategi Optimasi Bonus Demografi Jawa Barat. Bandung: Fakultas Ekonomi dan Bisnis Universitas Padjajaran.

The World Bank. (2002). Globalization, Growth, and Poverty Building an Inclusive World Economy. Washington, DC: the World Bank.

Tjiptoherijanto, P., \& Manurung, M. (2010). Paradigma Administrasi Publik dan Perkembangannya. Jakarta: UI-Press.

\section{Journal article}

Novianti, K. (2010). Analisis Trend dan Dampak Pengiriman TKI: Kasus Dua Desa di Lombok Timur, Nusa Tenggara Barat. Jurnal Kependudukan Indonesia, V(1), 15-39.

Ranis, G., \& Stewart, F. (2005, November). Dynamic Links between the Economy and Human Development. DESA Working Paper, 1-15.

Suharko. (2005). Masyarakat Sipil, Modal Sosial dan Tata Pemerintahan yang Demokratis. Jurnal Ilmu Sosial dan Ilmu Politik, 263-290. 